\title{
Systematic Literature Review: Efektivitas Ekstrak Kopi sebagai Antioksidan dalam Mengatasi Photoaging
}

\author{
Oktaviani Lestyaning Ratri ${ }^{1}$, Tamara Gusti Ebtavanny ${ }^{2 *}$, Oktavia Eka Puspita ${ }^{3}$ \\ 1,2,3.Program Studi Farmasi, Fakultas Kedokteran, Universitas Brawijaya, Malang, Indonesia
}

\begin{tabular}{l} 
INFO ARTIKEL \\
\hline Penerimaan \\
naskah: 09 \\
November 2021 \\
Penerimaan \\
naskah revisi: 13 \\
December 2021 \\
Disetujui untuk \\
dipublikasikan: \\
18 December \\
2021
\end{tabular}

Kata kunci :

Kopi,

Antioksidan,

Sinar UV,

Fotoaging

\section{A B S T R A K}

Penuaan pada kulit akibat paparan sinar UV disebut sebagai fotoaging. Fotoaging menyebabkan kulit menjadi kering, keriput, pigmentasi kulit bertambah gelap, serta kekencangan kulit berkurang. Efek fotoaging dapat diatasi oleh senyawa yang memiliki aktivitas antioksidan. Kopi memiliki kandungan polifenol (caffeic acid dan chlorogenic acid) yang dapat menghambat pembentukan radilkal bebas ROS. Hal tersebut menjadikan kopi sebagai antioksidan yang potensial dalam mengatasi fotoaging. Penelitian ini bertujuan untuk mengetahui efektivitas ekstrak kopi sebagai antioksidan dalam mengatasi photoaging. Metode yang digunakan pada penelitian ini yaitu Systematic Literature Review. Pencarian literatur yang komprehensif dilakukan menggunakan aplikasi Harzing's Publish or Perish pada beberapa database yaitu Google Scholar, PubMed, Scopus, dan Crossref dengan menggunakan kata kunci "coffee AND antioxidant AND ultraviolet AND photoaging”. Alur penyeleksian artikel yaitu menggunakan protokol Preferred Reporting Items for Systematic Reviews and Meta-analyses (PRISMA). Total hasil pencarian artikel yaitu sebanyak 1202 artikel, dan terdapat 6 artikel penelitian yang memenuhi kriteria inklusi dan eksklusi yang telah ditetapkan. Hasil penelitian ini menyimpulkan bahwa ekstrak kopi dapat digunakan sebagai antioksidan dalam mengatasi photoaging. Efektivitas ekstrak kopi sebagai antioksidan dalam mengatasi photoaging ditunjukkan dengan cara menurunkan ekspresi MMPs, meningkatkan ekspresi prokolage tipe 1, mengurangi area kerutan, dan menurunkan TEWL. Ekstrak daun kopi menurunkan ekspresi MMPs (persentase penurunan MMP-1 : 50\%; MMP-3 :10\% - 60\%;dan MMP-9 : 30\% - 50\%) dan meningkatkan prokolagen tipe 1 sebesar 60\%. Ekstrak biji kopi menurunkan ekspresi MMPs (persentase penurunan MMP-1 : 5\% - 60\%, MMP-2 : 20\% - 60\%, MMP-3 : 30\%, MMP$9: 20 \%-70 \%$, MMP-13 : 30\% - 45\%), meningkatkan prokolagen tipe 1 sebesar 10\% hingga 60\%, mengurangi area kerutan sebesar $20 \%$ hingga $88 \%$, dan menurunkan TEWL sebesar $10 \%$ hingga $20 \%$.

\section{Systematic Literature Review: The effectivity of Coffee Extract as An Antioxidant Againts Photoaging}

\author{
Keywords: \\ Coffee, \\ Antioxidant, \\ Ultraviolet, \\ Photoaging
}

$A B S T R A C T$

Aging of the skin due to exposure of UV rays is referred as photoaging. Photoaging causes dry skin, wrinkles, darker skin pigmentation, and reduced skin firmness. The effect of photoaging can be treated by compounds that have antioxidant activity. Coffee contains polyphenols (caffeic acid and chlorogenic acid) which can inhibit the formation of ROS free radicals. This makes coffee a potential antioxidant in photoaging treatment. This study aims to determine the effectiveness of coffee extract as an antioxidant in photoaging treatment. The method used in this study is Systematic Literature Review. A comprehensive literature search was conducted using the Harzing's Publish or Perish application on several databases, such as Google Scholar, PubMed, Scopus, and Crossref using keywords "coffee AND antioxidant AND ultraviolet AND photoaging". For selecting the article, the author uses the Preferred Reporting Items for Systematic Reviews and Meta-analyses (PRISMA) protocol. The total of the selected article was 1202 articles, and only 6 research articles matched the inclusion and exclusion criteria that had been set. The results of this study concluded that coffee extract can be used as an antioxidant in photoaging treatment. The effectiveness of coffee extract as an antioxidant in photoaging treatment was demonstrated by reducing the expression of MMPs, increasing the expression of type 1 procollage, reducing the area of wrinkles, and reducing TEWL. Coffee leaf extract decreased the expression of MMPs (decrease percentage of MMP-1 :50\%; MMP-3:10\% to 60\%; MMP-9:30\% to $50 \%$ ) and increased type 1 procollagen $60 \%$. Coffee bean extract decreased the expression of MMPs (MMP-1 :5\% to 60\%; MMP-2 :20\% to 60\%; MMP-3 :30\%; MMP-9 :20\% to 70\%; MMP-13: $30 \%$ to $45 \%$ ), increased type 1 procollagen $10 \%$ to $60 \%$, reduced wrinkle area $20 \%$ to $88 \%$, and decreased TEWL $10 \%$ to $20 \%$. 


\section{Pendahuluan}

Kulit merupakan bagian terluar dari tubuh yang berfungsi melindungi dari berbagai macam gangguan dan rangsangan dari luar. Sehingga kesehatan kulit sangat penting agar terhindar dari penyakit serta penuaan kulit (1). Penuaan pada kulit menjadi masalah utama bagi semua wanita. Penuaan kulit dapat disebabkan dari faktor intrinsik dan ekstrinsik. Penuaan kulit intrinsik merupakan proses penuaan kulit alami yang terjadi seiring bertambahnya usia. Sedangkan penuaan kulit ekstrinsik disebabkan oleh faktor yang berasal dari luar seperti ekspresi wajah berulang, polusi serta paparan sinar matahari terutama sinar ultraviolet (UV) (2). Penuaan kulit ekstrinsik yang dipengaruhi oleh sinar ultraviolet (UV) disebut juga sebagai photoaging.

Photoaging akibat paparan sinar UV dapat memicu radikal bebas (Reactive Oxygen Species (ROS). Aging yang terjadi karena paparan UV berlebihan disebut juga dengan fotoaging. Untuk mengatasi kerusakan sel dan stres oksidatif karena paparan UV, salah satunya dapat digunakan antioksidan(3). Antioksidan dibagi menjadi dua yaitu enzimatik dan non enzimatik. Antioksidan enzimatik antara lain: Superoksida Dismutase (SOD) dan katalase. Sedangkan antioksidan non enzimatik antara lain: vitamin C (asam askorbat), vitamin E (alfa tokoferol), dan flavonoid (polifenol) (4). Salah satu tanaman yang memiliki antioksidan polifenol cukup tinggi adalah kopi. Polifenol yang terkandung dalam tanaman kopi yaitu caffeic acid dan chlorogenic acid. Tanaman kopi dapat digunakan sebagai antioksidan karena memiliki kandungan polifenol dalam biji kopi sebesar 37-55 mg GAE/g dan daun kopi sebesar 12-77 mg GAE/g(5). Aktivitas antioksidan tanaman kopi diuji menggunakan uji DPPH (1,1-diphenyl-2-picrylhydrazyl), diperoleh bahwa ekstrak daun kopi memiliki nilai IC50 sebesar 35,24 ppm dan ekstrak biji kopi memiliki nilai IC50 sebesar 57,45 ppm dibandingkan dengan vitamin $\mathrm{C}$ yang memiliki IC50 sebesar 6,13 ppm. Hasil IC50<50 pmm menunjukkan aktivitas antioksidan yang sangat kuat sedangkan 50-100 ppm menunjukkan aktivitas antioksidan yang kuat (6).

Dari uraian di atas, peneliti ingin melakukan penelitian lebih lanjut menggunakan systematic literature review untuk mengetahui efektivitas aktivitas antioksidan yang ditimbulkan oleh kopi dalam mengatasi photoaging dengan melihat parameter MMPs (Matrix Metalloproteinase), prokolagen tipe 1, area kerutan, dan TEWL (Transepidermal Water Loss).

\section{Metode}

Jenis penelitian yang digunakan merupakan penelitian deskriptif dengan menggunakan metode Systematic Literature Review (SLR). Pencarian literatur yang komprehensif dilakukan menggunakan aplikasi Harzing's Publish or Perish pada beberapa database yaitu Google Scholar, PubMed, Scopus, dan Crossref dengan menggunakan kata kunci "coffee AND antioxidant AND ultraviolet AND photoaging". Alur penyeleksian artikel yaitu menggunakan protokol Preferred
Reporting Items for Systematic Reviews and Meta-analyses (PRISMA).

Kriteria inklusi pada penelitian ini antara lain: artikel penelitian dengan tahun publikasi 2011 hingga Mei 2021, artikel dengan bahasa Indonesia dan/atau Inggris; jenis penelitian pada artikel yang digunakan yaitu True Experimental, Quasi Experimental, Randomized Controlled Trial (RCT), dan Cohort; artikel dengan skor critical appraisal $\geq 50 \%$; serta artikel yang memenuhi PICO (Population: ekstrak kopi sebagai antioksidan dalam mengatasi photoaging; Intervention : ekstrak kopi dilakukan pengujian terhadap parameter photoaging (MMPs, prokolagen tipe 1, kerutan, dan TEWL ) secara in vitro, in vivo, maupun klinis; Outcome: efektivitas ekstrak kopi sebagai antioksidan dalam mengatasi photoaging (parameter photoaging : MMPs, prokolagen tipe 1, kerutan, dan TEWL)

Analisis kualitas data pada penelitian ini menggunakan Joanna Briggs Institute Critical Appraisal for QuasiExperimental Studies berisikan 9 pertanyaan. Setiap pertanyaan dengan jawaban "yes" akan mendapatkan poin +1 dan jawaban "no", "unclear", serta "not applicable" mendapatkan poin 0 .

\section{Hasil dan Diskusi}

\section{Hasil Sintesis Data}

Hasil pencarian artikel pada database Google Scholar, Crossref, dan Scopus ditampilkan dalam diagram dibawah ini (Gambar 1)

\section{Gambar 1.Diagram PRISMA}

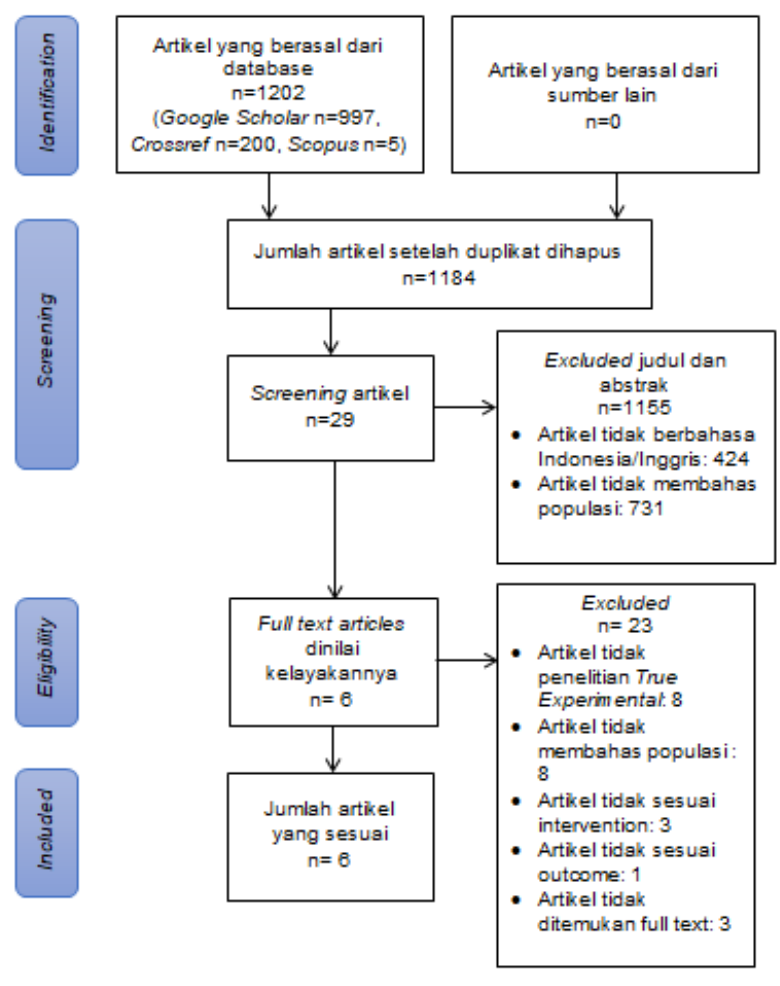




\section{Hasil Analisis Kualitas Data}

Artikel yang memiliki hasil analisis kualitas data dengan presentase $80-100 \%$, dianggap memiliki kualitas yang sangat baik, 50-79\% memiliki kualitas cukup baik dan <50\% memiliki kualitas yang kurang baik. Skor akhir dari penilaian kualitas data jika mencapai setidaknya 50\%, maka artikel tersebut memenuhi kriteria (7). Didapatkan 6 artikel yang memiliki persentase skor $\geq 50 \%$ (Tabel 1).

Tabel 1.Analisis Kualitas Data

\begin{tabular}{|c|c|c|c|c|c|c|c|c|c|c|c|}
\hline $\begin{array}{l}\text { Penulis } \\
\text { (Tahun) }\end{array}$ & $\begin{array}{l} \\
1\end{array}$ & $\begin{array}{l}\mathrm{P} \\
2 \\
\end{array}$ & $\begin{array}{l}\mathbf{P} \\
3 \\
\end{array}$ & $\begin{array}{l}\mathrm{P} \\
4 \\
\end{array}$ & $\begin{array}{l}\mathbf{P} \\
\mathbf{5} \\
\end{array}$ & $\begin{array}{l}P \\
6 \\
\end{array}$ & \begin{tabular}{l|} 
P \\
7 \\
\end{tabular} & \begin{tabular}{l|} 
P \\
8 \\
\end{tabular} & $\begin{array}{l}\text { P } \\
9\end{array}$ & Skor & Kesimpulan \\
\hline $\begin{array}{l}\text { Chiang et al. } \\
\text { (2011) }\end{array}$ & $\checkmark$ & $\checkmark$ & $\checkmark$ & $\checkmark$ & - & $\checkmark$ & $\checkmark$ & $\checkmark$ & $\checkmark$ & $\begin{array}{c}8 / 9 \\
(88,89 \\
\%)\end{array}$ & Sangat baik \\
\hline $\begin{array}{l}\text { Whoi et al. } \\
\text { (2015) }\end{array}$ & $\checkmark$ & $\checkmark$ & $\checkmark$ & $\checkmark$ & - & $\checkmark$ & - & $\checkmark$ & $\checkmark$ & $\begin{array}{c}7 / 9 \\
(77,78 \\
\%)\end{array}$ & Cukup baik \\
\hline $\begin{array}{c}\text { Choi et al. } \\
\text { (2016) }\end{array}$ & $\checkmark$ & $\checkmark$ & $\checkmark$ & $\checkmark$ & - & $\checkmark$ & - & $\checkmark$ & $\checkmark$ & $\begin{array}{c}7 / 9 \\
(77,78 \\
\%)\end{array}$ & Sangat baik \\
\hline $\begin{array}{l}\text { Wu et al. } \\
(2017)\end{array}$ & $\checkmark$ & $\checkmark$ & $\checkmark$ & $\checkmark$ & - & $\checkmark$ & $\checkmark$ & $\checkmark$ & $\checkmark$ & $\begin{array}{c}8 / 9 \\
(88,89 \\
\%)\end{array}$ & Sangat baik \\
\hline $\begin{array}{c}\text { Cho et al. } \\
\text { (2017) }\end{array}$ & $\checkmark$ & $\checkmark$ & $\checkmark$ & $\checkmark$ & - & $\checkmark$ & $\checkmark$ & $\checkmark$ & $\checkmark$ & $\begin{array}{c}8 / 9 \\
(88,89 \\
\%)\end{array}$ & Sangat baik \\
\hline $\begin{array}{l}\text { Mariati et al. } \\
(2021)\end{array}$ & $\checkmark$ & $\checkmark$ & $\checkmark$ & $\checkmark$ & $\checkmark$ & $\checkmark$ & $\checkmark$ & $\checkmark$ & $\checkmark$ & $\begin{array}{c}9 / 9 \\
(100 \% \\
)\end{array}$ & Sangat baik \\
\hline
\end{tabular}

\section{Profil Pencarian Artikel}

Pada profil pencarian artikel (Tabel 2) didapatkan 6 artikel yang sesuai dengan kriteria inklusi dan eksklusi. Penelitian dari keenam artikel seluruhnya dilakukan di Negara Asia, yaitu 2 Taiwan, 3 Korea, dan 1 Indonesia. Desain penelitian pada keenam artikel tersebut yaitu dua artikel (Chiang et al. 2011 dan Cho et al. 2017) menggunakan Quasi Experimental sedangkan 4 artikel (Choi et al. 2015; Choi et al. 2016; Wu et al. 2017; dan Mariati et al. 2021) menggunakan True Experimental.

Tabel 2.Profil Pencarian Artikel

\begin{tabular}{|c|c|c|c|c|c|c|}
\hline IS & $\begin{array}{c}\text { Penulis } \\
\text { (Tahunu) }\end{array}$ & Negara & $\begin{array}{c}\text { Jurnal dan } \\
\text { Impact } \\
\text { Factor }\end{array}$ & Desain Penelitim & $\begin{array}{c}\text { Objelk } \\
\text { Penelitian }\end{array}$ & Klasifikasi Tema \\
\hline 74 & $\begin{array}{l}\text { Chiang et } \\
\text { al(2011)( } \\
9)\end{array}$ & Taiwan & $\begin{array}{c}\text { Food and } \\
\text { Chemical } \\
\text { Toxicology } \\
(4,6)\end{array}$ & $\begin{array}{c}\text { Quasi } \\
\text { Experimental } \\
\text { (in vitro) }\end{array}$ & $\begin{array}{c}\text { Hioman } \\
\text { foreskin } \\
\text { ftbroblasts } \\
\text { (Ha68) }\end{array}$ & $\begin{array}{l}\text { - Penurunan elsapres } \\
\text { MMPs } \\
\text { - Peninglatan } \\
\text { prokolagen tipe } 1\end{array}$ \\
\hline 17 & $\begin{array}{l}\text { Choi et } \\
\text { al. } \\
(2015)(1 \\
0)\end{array}$ & Korea & $\begin{array}{c}\text { Journal of } \\
\text { Photochemist } \\
\text { 1y and } \\
\text { Photobiology } \\
B: \text { Biology } \\
(3,261)\end{array}$ & $\begin{array}{c}\text { True } \\
\text { Experimental } \\
\text { (in 1rio) }\end{array}$ & $\begin{array}{l}\text { Mencit } \\
\text { (SKH-1) } \\
\text { betina } \\
\text { tanpa bulu } \\
\text { benusia } 6 \\
\text { minggu }\end{array}$ & $\begin{array}{l}\text { - Penurunan elspres } \\
\text { MNMs } \\
\text { - Peninglatan } \\
\text { - prokolagen tipe } 1 \\
\text { - Penurunan area } \\
\text { kerutan } \\
\text { - Penurunan TEWL } \\
\text { - }\end{array}$ \\
\hline 13 & $\begin{array}{l}\text { Choi et } \\
\text { al. } \\
(2016)(1 \\
1)\end{array}$ & Korea & $\begin{array}{c}\text { Photochemica } \\
\text { l \& } \\
\text { Photobiologic } \\
\text { al Sciences } \\
(2,902)\end{array}$ & $\begin{array}{c}\text { True } \\
\text { Experimental } \\
\text { (in 1rio) }\end{array}$ & $\begin{array}{c}\text { Mencit } \\
\text { (SKH-1) } \\
\text { betina } \\
\text { tampa bulu } \\
\text { berusia } 6 \\
\text { minggu }\end{array}$ & $\begin{array}{ll}\text { - } & \text { Penurunan elsppres } \\
\text { MNMP } \\
\text { - Peningkatan } \\
\text { - prokolagen tipe } 1 \\
\text { - Penurunan area } \\
\text { - kerutan } \\
\text { - Penurunan TEWL }\end{array}$ \\
\hline 27 & $\begin{array}{l}\text { Wu et al. } \\
(2017)(1 \\
2)\end{array}$ & Triwan & $\begin{array}{l}\text { Dnternational } \\
\text { Journal of } \\
\text { Molectular } \\
\text { Sciences } \\
(4,556)\end{array}$ & $\begin{array}{c}\text { True } \\
\text { Experimental } \\
\text { (in 1rio) }\end{array}$ & $\begin{array}{c}\text { Mencit } \\
\text { (balb/c) } \\
\text { betina } \\
\text { tanpa bulu } \\
\text { berusia } 5 \\
\text { minggu }\end{array}$ & $\begin{array}{ll}\text { - } & \text { Penurunan elspres } \\
\text { MNMPs } \\
\text { - Penurunan area } \\
\text { kerutan } \\
\text { - Penurunan TEWL }\end{array}$ \\
\hline 16 & $\begin{array}{l}\text { Cho et al. } \\
(2017)(1 \\
3)\end{array}$ & Korea & $\begin{array}{c}\text { Journal of } \\
\text { Photochemist } \\
\text { ry and } \\
\text { Photobiology } \\
\text { B: Biology } \\
(3,261)\end{array}$ & $\begin{array}{c}\text { Quasi } \\
\text { Experimental } \\
\text { (in vitro) }\end{array}$ & $\begin{array}{l}\text { Mouse } \\
\text { fibroblast } \\
\text { cell line } \\
\text { (CCRF) }\end{array}$ & $\begin{array}{ll}\text { - Penurunan elspres } \\
\text { MMMs } \\
\text { - Peninglatan } \\
\text { prokolaggen tipe } 1\end{array}$ \\
\hline 0 & $\begin{array}{l}\text { Mariati et } \\
\text { al. } \\
(2021)(1 \\
4)\end{array}$ & Indonesia & $\begin{array}{c}\text { The } \\
\text { Dndonesian } \\
\text { Biomedical } \\
\text { Joirnal } \\
(0,45)\end{array}$ & $\begin{array}{c}\text { True } \\
\text { Experimental } \\
\text { (in 1rio) }\end{array}$ & $\begin{array}{c}\text { Mencit } \\
\text { (Mus } \\
\text { musculus } \\
\text { balb/c) } \\
\text { benumur } \\
4 \text { minggu } \\
\text { dan berat } \\
25 \pm 5 \text { gr } \\
\end{array}$ & $\begin{array}{ll}\text { - } & \text { Penurunan elspres } \\
\text { MMMs } \\
\text { - Penurunan area } \\
\text { kerutan }\end{array}$ \\
\hline
\end{tabular}

Pada hasil artikel yang didapatkan, terdapat satu artikel yang memiliki Indeks Sitasi (IS) 0 (Mariati et al. 2021). Hal tersebut kemungkinan karena tahun penerbitan artikel yang masih baru yaitu pada Maret 2021 sehingga masih jarang penulis yang mensitasi artikel tersebut. Keenam artikel yang didapatkan juga memiliki impact factor. Impact factor merupakan skala berapa kali jurnal telah dikutip untuk menentukan seberapa baik jurnal tersebut sehingga menyebabkan peneliti menerbitkan artikel pada jurnal tersebut. Namun impact factor tidak berpengaruh pada kualitas artikel karena hanya upaya untuk mengukur peringkat jurnal yang terbit pada rentang waktu tertentu (8).

\section{Efektivitas Ekstrak Kopi}

a. Pengaruh Ekstrak Kopi terhadap penurunan ekspresi MMPs dan peningkatan prokolagen tipe 1

Photoaging merupakan penuaan kulit akibat adanya paparan sinar UV dari matahari. Radiasi dari UVB dapat menginduksi produksi ROS. ROS mengaktivasi Mitogenactivated protein kinase (MAPK) yang merupakan jalur photoaging dan faktor produksi MMP dalam fibroblast. $c$-Jun NH2 teeminal kinase (JNK) dan p38 memodulasi ekspresi cFos. Lalu c-Fos dan c-Jun mensintesis activator protein-1 (AP1) yang akan menginduksi sintesis Matrix Metalloproteinases (MMPs) yang berperan dalam degradasi kolagen (15).

Berdasarkan hasil pada Tabel 3, dapat disimpulkan bahwa ekstrak kopi dapat menurunkan ekspresi MMPs dan meningkatkan prokolagen tipe 1 . Hasil tersebut sesuai dengan penelitian yang dilakukan Bessada, Alves and Oliveira (2018) yang menyebutkan bahwa kopi memiliki efek $u v$ protection karena mengandung senyawa polifenol (caffeic acid dan chlorogenic acid) yang secara efektif menekan ekspresi MMPs seperti MMP-1, MMP-3, dan MMP-9 serta memiliki potensi untuk meningkatkan sintesis prokolagen dalam fibroblas, sehingga dapat efektif untuk mengurangi photoaging yang mengarah pada pembentukan kerutan (3)(16).

Penurunan ekspresi MMPs disebabkan karena adanya penghambatan aktivasi MAP kinase. Kandungan kopi yaitu polifenol (caffeic acid dan chlorogenic acid) menghambat aktivasi MAP kinase. Polifenol menghambat ekspresi ERK, JNK dan p38 (yang memodulasi ekspresi c-Fos) sehingga dapat menekan ekspresi c-Fos dan c-Jun dan kemudian menghambat ekspresi AP-1, sehingga dapat menurunkan ekspresi MMPs dan tidak terjadi degradasi kolagen. Dengan demikian, penghambatan produksi ROS tersebut akan mencegah kulit dari photoaging(17).

\section{b. Pengaruh Ekstrak kopi terhadap penurunan area kerutan}

Kerutan dapat terjadi karena paparan UV dapat menginduksi terbentuknya ROS. Kemudian ROS akan menurunkan ekspresi TGF- $\beta$ yang menyebabkan turunnya produksi kolagen sehingga menghasilkan perubahan dalam struktur kulit yang secara klinis dimanifestasikan oleh kerutan dalam, tekstur kasar, telangiektasia dan pigmentasi (18).

Berdasarkan hasil pada Tabel 3, dapat disimpulkan bahwa ekstrak kopi dapat menurunkan area kerutan. Hasil tersebut 
sesuai dengan penelitian yang dilakukan oleh Rodrigues et al., (2016) yang menunjukkan bahwa ekstrak kopi dapat mengurangi kerutan pada 20 sukarelawan manusia, menggunakan krim berbasis ekstrak kopi, dua kali sehari, selama 28 hari. Pada penelitian tersebut membandingkan krim ekstrak kopi dengan krim yang mengandung HyaCare ${ }^{\circledR}$ Filler CL (polisakarida ikatan silang yang dibuat dari asam hialuronat yang difermentasi). Hasilnya menunjukkan bahwa ekstrak kopi terbukti menjadi bahan yang efektif untuk anti kerutan dengan hasil yang mirip dengan asam hialuronat (19). Pengurangan area kerutan terjadi karena polifenol yang terdapat pada kopi, meningkatkan ekspresi TGF- $\beta$ yang merupakan sitokin yang meningkatkan produksi kolagen, sehingga dapat meningkatkan produksi kolagen dan menyebabkan area kerutan berkurang (17).

Tabel 3. Efektivitas Ekstrak Kopi

\begin{tabular}{|c|c|c|c|c|}
\hline $\begin{array}{l}\text { Peneliti } \\
\text { (Tahun) }\end{array}$ & $\begin{array}{c}\text { Jenis } \\
\text { Produk } \\
\text { Ektrak } \\
\text { Kopi }\end{array}$ & $\begin{array}{c}\text { Tujuan } \\
\text { Penelitian }\end{array}$ & $\begin{array}{l}\text { Desain Perlakuan } \\
\text { dan Pengukuran } \\
\text { Objek Penelitian }\end{array}$ & $\begin{array}{c}\text { Hasil } \\
\text { Penelitian }\end{array}$ \\
\hline $\begin{array}{l}\text { Chiang et } \\
\text { al. } \\
(2011)(9)\end{array}$ & $\begin{array}{l}\text { Ekstrak } \\
\text { daun } \\
\text { kopi }\end{array}$ & $\begin{array}{l}\text { Untuk } \\
\text { menyelidiki } \\
\text { potensi ekstrak } \\
\text { daun kopi dalam } \\
\text { menurunkan } \\
\text { MMP-1, -3 dan - } \\
9 \text { yang diinduksi } \\
\text { UVB dan } \\
\text { reduksi } \\
\text { prokolagen tipe I } \\
\text { yang dinduksi } \\
\text { UVB. }\end{array}$ & $\begin{array}{l}\text { Perlakuan objek } \\
\text { Penelitian: } \\
\text { fibroblast } \\
\text { diiradiasi UVB } \\
\text { pada dosis } \\
\text { paparan } 80 \\
\text { mJ/cm² selama } \\
30 \text { detik } \rightarrow \\
\text { dibiarkan } \\
\text { semalaman lalu } \\
\text { dibagi } 4 \\
\text { kelompok yaitu } \\
\text { kelompok } \\
\text { kontrol UVB, } \\
\text { kelompok } \\
\text { perlakuan yang } \\
\text { diberikan } 50 \mu \mathrm{L} \\
\text { ekstrak daun } \\
\text { kopi dengan } \\
\text { konsentrasi } 5, \\
10, \text { dan } 25 \\
\mu L / m L \text { yang } \\
\text { dilarutkan } \\
\text { dalam DMEM } \\
\text { dengan } \\
\text { beberapa } \\
\text { DMSO selama } \\
24 \text { jam } \\
\text { - Uji ekspresi } \\
\text { MMPs dan } \\
\text { kolagen tipe } 1 \\
\text { dengan western } \\
\text { blot analysis }\end{array}$ & 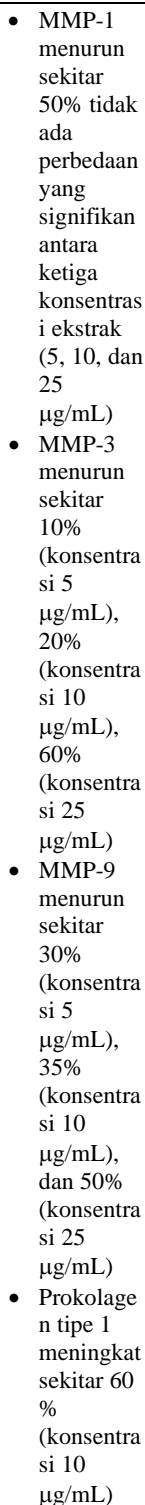 \\
\hline Choi et al. & $\begin{array}{l}\text { Ekstrak } \\
\text { biji }\end{array}$ & Untuk menguji & $\begin{array}{l}\text { - Perlakuan } \\
\text { subjek }\end{array}$ & - $\begin{array}{l}\text { Hasil } \\
\text { ujiwestern }\end{array}$ \\
\hline
\end{tabular}

\begin{tabular}{|c|c|c|c|c|}
\hline$(2015)(10)$ & kopi & $\begin{array}{l}\text { efek ekstrak biji } \\
\text { kopi yang } \\
\text { diberikan secara } \\
\text { oral terhadap } \\
\text { photoaging kulit } \\
\text { yang diinduksi } \\
\text { UV }\end{array}$ & $\begin{array}{l}\text { penelitian: } \\
\text { Mencit betina } \\
\text { tanpa bulu } \\
\text { berusia } 6 \\
\text { minggu dibagi } \\
\text { menjadi } 4 \\
\text { kelompok } \\
\text { secara acak (5 } \\
\text { mencit/kelompo } \\
\text { k) yang terdiri } \\
\text { dari kelompok } \\
\text { normal, } \\
\text { kelompok } \\
\text { kontrol UVB, } \\
\text { kelompok } \\
\text { UVB+0,1\% } \\
\text { ekstrak, dan } \\
\text { kelompok } \\
\text { UVB+0,5\% } \\
\text { ekstrak dalam } \\
\text { air minum. } \\
\text { Paparan UVB } \\
\text { (290-320 nm) } \\
\text { dilakukan } 3 \text { kali } \\
\text { seminggu } \\
\text { selama } 12 \\
\text { minggu, dengan } \\
\text { dosis } 36 \\
\text { mJ/cm², yang } \\
\text { kemudian } \\
\text { ditingkatkan } \\
\text { menjadi } 54,72, \\
\text { 90, 108, 126, } \\
144,162,180, \\
\text { dan } 198 \text { mJ/cm² } \\
\text { - Uji ekspresi } \\
\text { MMPs dengan } \\
\text { western blot } \\
\text { analysis } \\
\text { - Uji TEWL } \\
\text { dengan } \\
\text { Tewameter TM } \\
\text { 300 } \\
\text { - Uji ekspresi } \\
\text { MMPs dan } \\
\text { kolagen tipe } 1 \\
\text { dengan } \\
\text { immunohistoche } \\
\text { mistry analysis } \\
\text { Uji area kerutan } \\
\text { dengan } \\
\text { Macroscopic } \\
\text { Skin Analysis }\end{array}$ & $\begin{array}{l}\text { blot } \\
\text { analysis: } \\
\text { ekspresi } \\
\text { MMP-2 } \\
\text { menurun } \\
\text { lebih dari } \\
60 \% \\
\text { (tidak ada } \\
\text { perbedaan } \\
\text { yang } \\
\text { signifikan } \\
\text { antara } \\
\text { kedua } \\
\text { konsentras } \\
\text { i ekstrak } \\
\text { (0,1 dan } \\
0,5 \%) \\
\text { dan } \\
\text { ekspresi } \\
\text { MMP-9 } \\
\text { menurun } \\
\text { sekitar } \\
\text { 60\% } \\
\text { (konsentra } \\
\text { si 0,1\%) } \\
\text { dan 70\% } \\
\text { (konsentra } \\
\text { si 0,5\%) } \\
\text { Hasil uji } \\
\text { TEWL: } \\
\text { menurun } \\
\text { sekitar } \\
15 \% \\
\text { (konsentra } \\
\text { si 0,1\%) } \\
\text { dan 20\% } \\
\text { (konsentra } \\
\text { si 0,5\%) } \\
\text { Hasil } \\
\text { ujiimmuno } \\
\text { histochem } \\
\text { istry } \\
\text { analysis: } \\
\text { prokolage } \\
\text { n tipe } 1 \\
\text { meningkat } \\
\text { yaitu 20\% } \\
\text { (konsentra } \\
\text { si 0,1\%) } \\
\text { dan 40\% } \\
\text { (konsentra } \\
\text { si 0,5\%) } \\
\text { Sedangka } \\
\text { n ekspresi } \\
\text { MMP-2 } \\
\text { menurun } \\
20 \% \\
\text { (konsentra } \\
\text { si 0,1\%) } \\
\text { dan 30\% } \\
\text { (konsentra } \\
\text { si 0,5\%) } \\
\text { Hasil } \\
\text { ujiMacros } \\
\text { copic Skin } \\
\text { Analysis : } \\
\text { area } \\
\text { kerutan } \\
\text { berkurang } \\
\text { sebesar } \\
30 \% \\
\text { (tidak ada } \\
\text { perbedaan } \\
\text { yang } \\
\text { signifikan } \\
\text { antara } \\
\text { kedua } \\
\text { konsentras } \\
\text { i ekstrak } \\
\text { (0,1 dan } \\
0,5 \%) \\
\end{array}$ \\
\hline $\begin{array}{l}\text { Choi et al. } \\
(2016)(11)\end{array}$ & $\begin{array}{l}\text { Ekstrak } \\
\text { biji } \\
\text { kopi }\end{array}$ & $\begin{array}{l}\text { Untuk menguji } \\
\text { efek ekstrak biji }\end{array}$ & $\begin{array}{l}\text { - Perlakuan } \\
\text { subjek } \\
\text { penelitian: }\end{array}$ & $\begin{array}{l}\text { - Hasil uji } \\
\text { real-time } \\
\text { polymeras }\end{array}$ \\
\hline
\end{tabular}




\begin{tabular}{|c|c|c|c|c|}
\hline & & $\begin{array}{l}\text { kopi yang } \\
\text { diberikan secara } \\
\text { topikal terhadap } \\
\text { photoaging kulit } \\
\text { yang diinduksi } \\
\text { UV }\end{array}$ & 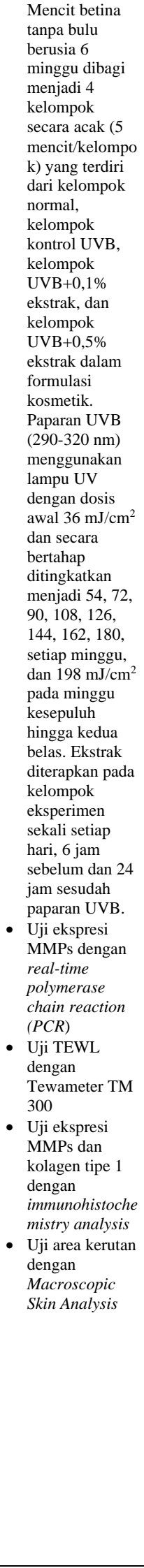 & 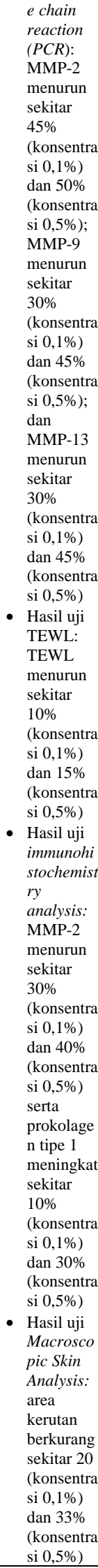 \\
\hline $\begin{array}{l}\text { Wu et al. } \\
(2017)(12)\end{array}$ & $\begin{array}{l}\text { Ekstrak } \\
\text { biji } \\
\text { kopi }\end{array}$ & $\begin{array}{l}\text { Untuk } \\
\text { menyelidiki } \\
\text { potensi ekstrak }\end{array}$ & $\begin{array}{l}\text { - Perlakuan } \\
\text { subjek } \\
\text { penelitian:menc } \\
\text { it betina tidak }\end{array}$ & $\begin{array}{l}\text { - Hasil } \\
\text { ujiimmuno } \\
\text { histochem } \\
\text { istry }\end{array}$ \\
\hline
\end{tabular}

\begin{tabular}{|c|c|c|c|c|}
\hline & & $\begin{array}{l}\text { biji kopi dalam } \\
\text { melawan stres } \\
\text { oksidatif yang } \\
\text { diinduksi radiasi } \\
\text { UVB dan } \\
\text { photodamage } \\
\text { pada mencit } \\
\text { tanpa bulu }\end{array}$ & 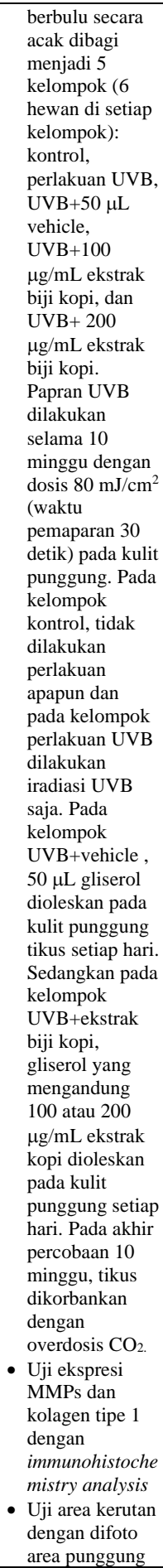 & $\begin{array}{l}\text { analysis: } \\
\text { Pada } \\
\text { kelompok } \\
\text { dengan } \\
\text { perlakuan } \\
\text { ekstrak } \\
200 \\
\mu \mathrm{g} / \mathrm{mL} \\
\text { terlihat } \\
\text { sangat } \\
\text { menguran } \\
\text { gi bercak } \\
\text { coklat } \\
\text { yang } \\
\text { terbentuk } \\
\text { dibanding } \\
\text { kan } \\
\text { kelompok } \\
\text { kontrol } \\
\text { UVB } \\
\text { sehingga } \\
\text { pengobata } \\
\text { n dengan } \\
\text { ekstrak } \\
\text { biji kopi } \\
\text { efektif } \\
\text { dalam } \\
\text { menekan } \\
\text { efek } \\
\text { MMP-1 } \\
\text { - Hasil } \\
\text { TEWL: } \\
\text { TEWL } \\
\text { berkurang } \\
\text { sekitar } \\
10 \% \\
\text { (konsentra } \\
\text { si } 100 \\
\mu \text { g/mL) } \\
\text { dan } 15 \% \\
\text { (konsentra } \\
\text { kerutan: } \\
\text { Ag/mL) } \\
\text { Aplikasi } \\
\text { ekstrak } \\
\text { biji kopi } \\
\text { secara } \\
\text { topikal } \\
\text { gi } 100 \text { dan } \\
\text { pemburan } \\
\text { kan } \\
\text { kerutan }\end{array}$ \\
\hline $\begin{array}{l}\text { Cho et al. } \\
(2017)(13)\end{array}$ & $\begin{array}{l}\text { Ekstrak } \\
\text { biji } \\
\text { kopi }\end{array}$ & $\begin{array}{l}\text { Untuk } \\
\text { mengidentifikasi } \\
\text { dan } \\
\text { mengevaluasi } \\
\text { efek anti- } \\
\text { kerutan dari biji } \\
\text { kopi dengan } \\
\text { memeriksa } \\
\text { tingkat ekspresi } \\
\text { MMP-1, MMP- } \\
\text { 3, dan MMP-9, } \\
\text { serta regulasi }\end{array}$ & $\begin{array}{l}\text { - Perlakuan } \\
\text { subjek } \\
\text { penelitian: Sel } \\
\text { CCRF diberi } \\
\text { paparan radiasi } \\
\text { UV-B }(312 \mathrm{~nm}) \\
\text { pada } 80 \mathrm{~mJ} / \mathrm{cm} 2 \\
\text { selama } 60 \text { detik } \\
\rightarrow \text { dikultur } \\
\text { selama } 24 \text { jam } \\
\text { dalam media } \\
\text { yang dilengkapi } \\
\text { dengan berbagai } \\
\text { konsentrasi } \\
(6,25,12,5,25 \\
\text { dan } 50 \mu \mathrm{g} / \mathrm{ml}) \\
\text { ekstrak biji kopi }\end{array}$ & 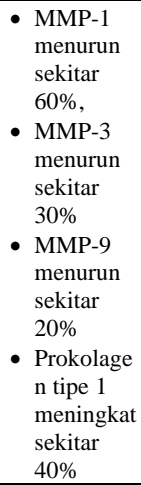 \\
\hline
\end{tabular}




\begin{tabular}{|c|c|c|c|c|}
\hline & & $\begin{array}{l}\text { prokolagen tipe- } \\
\text { I dalam sel } \\
\text { CCRF yang } \\
\text { disinari dengan } \\
\text { sinar UV-B. }\end{array}$ & $\begin{array}{l}\text { - Uji ekspresi } \\
\text { MMPs dan } \\
\text { kolagen tipe } 1 \\
\text { dengan western } \\
\text { blot analysis }\end{array}$ & $\begin{array}{l}\text { (tidak ada } \\
\text { perbedaan } \\
\text { yang } \\
\text { signifikan } \\
\text { antara } \\
\text { keempat } \\
\text { konsentrasi } \\
(6,25 ; 12,5 \text {; } \\
25 ; 50 \\
\mu \mathrm{g} / \mathrm{mL}) .\end{array}$ \\
\hline $\begin{array}{l}\text { Mariati et } \\
\text { al. } \\
(2021)(14)\end{array}$ & $\begin{array}{l}\text { Ekstrak } \\
\text { biji } \\
\text { kopi }\end{array}$ & $\begin{array}{l}\text { Untuk meneliti } \\
\text { efek krim } \\
\text { ekstrak biji kopi } \\
\text { untuk mencegah } \\
\text { kerutan pada } \\
\text { kulit mencit } \\
\text { yang diberi } \\
\text { perlakuan UVB. }\end{array}$ & 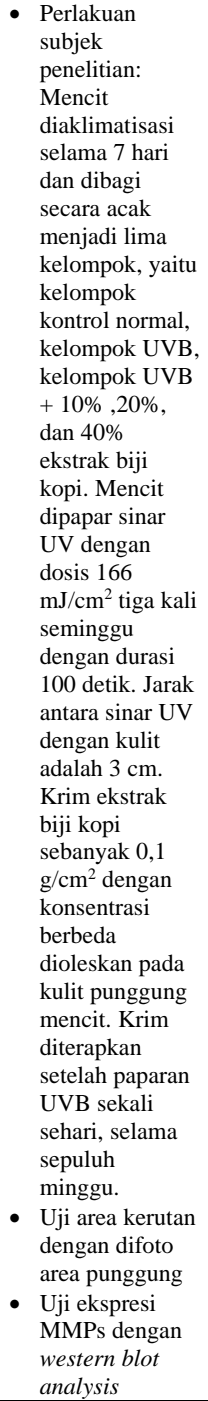 & $\begin{array}{l}\text { - Hasil uji } \\
\text { area } \\
\text { kerutan: } \\
\text { area } \\
\text { kerutan } \\
\text { berkurang } \\
\text { sekitar } \\
30 \% \\
\text { (konsentra } \\
\text { si 40\%), } \\
67 \% \\
\text { (konsentra } \\
\text { si 20\%), } \\
\text { dan 88\% } \\
\text { (konsentra } \\
\text { si 10\%) } \\
\text { Hasil uji } \\
\text { western } \\
\text { blot } \\
\text { analysis: } \\
\text { ekspresi } \\
\text { MMP-1 } \\
\text { menurun } \\
\text { sekitar 5\% } \\
\text { (konsentra } \\
\text { si 10\%), } \\
20 \% \\
\text { (konsentra } \\
\text { si } 40 \% \text { ) } \\
\text { dan 50\% } \\
\text { (konsentra } \\
\text { si 20\%) }\end{array}$ \\
\hline
\end{tabular}

\section{c. Pengaruh ekstrak kopi terhadap penurunan TEWL}

Transepidermal water loss (TEWL) adalah jumlah air yang menguap secara pasif melalui kulit ke lingkungan luar. TEWL yang tinggi berhubungan dengan disfungsi barier kulit yang menimbulkan kulit kering (20).

Berdasarkan hasil pada Tabel 3, dapat disimpulkan bahwa ekstrak kopi dapat menurunkan TEWL. Hasil tersebut sesuai dengan penelitian yang dilakukan Rodrigues et al. (2015) yang menunjukkan bahwa kadar TEWL menurun serta sawar kulit membaik dengan ditandai dengan kadar hidrasi kulit yang meningkat pada 15 orang wanita dan 5 pria yang diberikan perlakuan krim ekstrak kopi selama 30 hari (21).

Penurunan TEWL dapat terjadi karena adanya aktivitas penghambatan hyaluronidase (enzim yang dapat mendegradasi asam hialuronat pada kulit yang dapat menurunkan viskositas, meningkatkan permeabilitas, dan menyebabkan kerusakan matriks ekstraseluler (serat kolagen dan elastin) sehingga mengakibatkan kulit menjadi kering) dari kandungan polifenol kopi yatu caffeic acid dan chlorogenic acid yang dapat meningkatkan hidrasi kulit serta kekencangan kulit (16)(22)

\section{Profil Ekstrak Kopi}

Pada Tabel 4, diketahui terdapat 1 artikel menggunakan ektrak daun kopi dan 5 artikel menggunakan ekstrak biji kopi. Ekstrak daun kopi memiliki aktivitas antioksidan yang lebih bagus daripada ekstrak biji kopi. Namun, pada data artikel yang diperoleh, hanya terdapat 1 artikel yang membahas ekstrak daun dalam mengatasi photoaging. Hal tersebut disebabkan daun tidak tahan terhadap suhu pemanasan yang terlalu tinggi sehingga membutuhkan metode ekstraksi non termal yang efektif dan efisien yaitu dengan menggunakan metode ekstraksi ultrasonik. Sedangkan biji kopi dapat diekstraksi menggunakan metode ekstraksi konvensional yaitu menggunakan metode maserasi. Rendemen yang dihasilkan oleh metode ultrasonik lebih tinggi daripada metode maserasi. Namun, metode ultrasonik membutuhkan energi dan biaya yang besar sehingga masih jarang digunakan (23).

Tabel 4.Profil Produk Ekstrak Kopi

\begin{tabular}{|c|c|c|}
\hline $\begin{array}{c}\text { Penulis } \\
\text { (Tahun) }\end{array}$ & Konsentrasi Ekstrak Kopi & Jenis Ekstrak Kopi \\
\hline $\begin{array}{c}\text { Chiang et al. } \\
(2011)\end{array}$ & $5 ; 10 ; 25 \mu \mathrm{g} / \mathrm{mL}$ & Ekstrak daun kopi \\
\hline $\begin{array}{c}\text { Choi et al. } \\
(2015)\end{array}$ & $0,1 \% ; 0,5 \%$ & Ekstrak biji kopi \\
\hline $\begin{array}{c}\text { Choi et al. } \\
(2016)\end{array}$ & $0,1 \% ; 0,5 \%$ & Ekstrak biji kopi \\
\hline $\begin{array}{c}\text { Wu et al. } \\
(2017)\end{array}$ & $100 \mu \mathrm{g} / \mathrm{mL}, 200 \mu \mathrm{g} / \mathrm{mL}$ & Ekstrak biji kopi \\
\hline $\begin{array}{c}\text { Cho et al. } \\
(2017)\end{array}$ & 6,$25 ; 12,5 ; 25 ; 50 \mu \mathrm{g} / \mathrm{mL}$ & Ekstrak biji kopi \\
\hline $\begin{array}{c}\text { Mariati et al. } \\
(2021)\end{array}$ & $10,20,40 \%$ & Ekstrak biji kopi \\
\hline \multicolumn{2}{|c}{} \\
\hline
\end{tabular}

\section{Kesimpulan}

Berdasarkan hasil systematic literature review, dapat diambil kesimpulan bahwa ekstrak kopi dapat digunakan sebagai antioksidan dalam mengatasi photoaging dengan cara: Menurunkan ekspresi MMPs(persentase penurunan MMP-1 : 50\%; MMP-3 : 10\% - 60\%; dan MMP-9 : 30\% - 50\%) dan meningkatkan prokolagen tipe 1 sebesar $60 \%$. Ekstrak biji kopi menurunkan ekspresi MMPs (persentase penurunan MMP-1 : 5\% - 60\%, MMP-2 : 20\% - 60\%, MMP-3 : 30\%, MMP-9 : 20\% - 70\%, MMP-13: 30\% - 45\%), meningkatkan prokolagen tipe 1 sebesar $10 \%$ hingga $60 \%$, mengurangi area kerutan sebesar $20 \%$ hingga $88 \%$, dan menurunkan TEWL sebesar $10 \%$ hingga $20 \%$. 


\section{Daftar Pustaka}

1. Jeschke MG, van Baar ME, Choudhry MA, Chung KK, Gibran NS, Logsetty S. Burn injury. Nature Reviews Disease Primers. 2020;6(1).

2. Romanowski KS, Palmieri TL. Pediatric burn resuscitation: Past, present, and future. Burn Trauma. 2017;5(1):1-9.

3. Gülhan B, Kanlk Yüksek S, Hayran M, Özkaya Parlakay A, Güney D, Akln Kağlzmanll G, et al. Infections in Pediatric Burn Patients: An Analysis of One Hundred Eighty-One Patients. Surgical Infections (Larchmt). 2020;21(4):356-61.

4. Duke JM, Rea S, Boyd JH, Randall SM, Wood FM. Mortality after burn injury in children: A 33 -year populationbased study. Pediatrics. 2015;135(4):e903-10.

5. Nielson CB, Duethman NC, Howard JM, Moncure M, Wood JG. Burns: Pathophysiology of Systemic Complications and Current Management. Journal of Burn Care \& Research. 2017;38(1):469-81.

6. Lopez ON, Cambiaso-Daniel J, Branski LK, Norbury WB, Herndon DN. Predicting and managing sepsis in burn patients: Current perspectives. Therapeutics and Clinical Risk Management. 2017;13:1107-17.

7. Ramos G. Antibiotic Prophylaxis in Burn Patients: A Review of Current Trends and Recommendations for Treatment. Journal of Infection. 2018;1(1):1-5.

8. Csenkey A, Jozsa G, Gede N, Pakai E, Tinusz B, Rumbus $Z$, et al. Systemic antibiotic prophylaxis does not affect infectious complications in pediatric burn injury: A metaanalysis. PLoS One. 2019;14(9):1-13.

9. Romandini A, Pani A, Schenardi PA, Pattarino GAC, De Giacomo C, Scaglione F. Antibiotic resistance in pediatric infections: Global emerging threats, predicting the near future. Antibiotics. 2021;10(4):1-12.

10. Junior IWJ, Suka Adnyana IM, Subawa IW, Putri VP. Pola Kuman dan Uji Kepekaan Antibiotik Pada Pasien Unit Luka Bakar RSUP Sanglah Periode 1 Januari 2016 - 1 Januari 2017. Intisari Sains Medis. 2019;10(2):201-6.

11. van Langeveld I, Gagnon RC, Conrad PF, Richard L. Multiple-drug resistance in burn patients: a retrospective study on the impact of antibiotic resistance on survival and length of stay. Journal of Burn Care \& Research. 2017; 38(2):99-105 12. Aisyah S, Yulia R, Saputro ID, Herawati F. Evaluation of antibiotic use and bacterial profile in burn unit patients at the Dr. Soetomo general hospital. Annals of Burns and Fire Disasters. 2018;31(3):194-7.

13. Satari HI, Firmansyah A, Theresia T. Qualitative evaluation of antibiotic usage in pediatric patients. Paediatrica Indonesiana. 2011;51(6):303.

14. WHO. ATC/DDD index 2021 [Internet]. [cited $2021 \mathrm{Mar}$ 28]. Available from: https://www.whocc.no/atc_ddd_index/

15. Bourgi J, Yaacoob E, Berberi M, Chedid M, Sfeir P, Yaacoub $\mathrm{C}$, et al. Factors affecting length of stay among pediatric and adult patients admitted to the lebanese burn centre: A retrospective study. Annals of Burns and Fire Disasters. 2019;32(3):216-21.

16. Saputro ID, Putra ON, Hardiyono, Mufidah E. "Offlabel" medicine use in burned children: three-year retrospective study. Annals of Burns and Fire Disasters. 2021;34(1):18-25.

17. Chen YY, Wu PF, Chen CS, Chen IH, Huang WT, Wang $F$ Der. Trends in microbial profile of burn patients following an event of dust explosion at a tertiary medical center. $B M C$ Infectious Diseases. 2020;20(1):1-11.

18. Rachmawati S, Masito DK, Rachmawati E. Evaluasi Penggunaan Antibiotik pada Pasien Anak Rawat Inap di RSD Dr. Soebandi Jember. Jurnal Farmasi Galenika (Galenika Journal of Pharmacy). 2020;6(2):212-20.

19. Sonda TB, Horumpende PG, Kumburu HH, van Zwetselaar M, Mshana SE, Alifrangis M, et al. Ceftriaxone use in a tertiary care hospital in Kilimanjaro, Tanzania: A need for a hospital antibiotic stewardship programme. PLoS One. 2019;14(8):1-11.

20. Feng Y, van Hest RM, Hodiamont CJ, Brul S, Schultsz C, ter Kuile BH. Optimization of therapy against Pseudomonas aeruginosa with ceftazidime and meropenem using chemostats as model for infections. FEMS Microbiology Letters. 2017;364(14):1-8.

21. Dou Y, Huan J, Guo F, Zhou Z, Shi Y. Pseudomonas aeruginosa prevalence, antibiotic resistance and antimicrobial use in Chinese burn wards from 2007 to 2014. Journal of International Medical Research. 2017;45(3):1124-37.

22. Bassetti M, Peghin M, Vena A, Giacobbe DR. Treatment of Infections Due to MDR Gram-Negative Bacteria. Frontiers in Medicine. 2019;6(April):1-10.

23. BNF, 2020. British National Formulary $80^{\text {th }}$ edition, BMJ Group, London.

24. Chan CH, Yang SF, Yeh HW, Yeh YT, Wang YH, Teng $\mathrm{YH}$, et al. Risk of pneumonia in patients with burn injury: A population-based cohort study. Clinical Epidemiology. 2018;10:1083-91.

25. Putra ON, Saputro ID, Faizah AK. Case Report: Expanded-Spectrum Beta Lactamase-Producing Klebsiella pneumoniae in Burn Injury With Hospital Acquired Pneumonia. Pharmentical Journal of Indonesia. 2020;5(2):79-83.

26. Amalia S. Studi Penggunaan Antibiotika Pada Pasien Luka Bakar. Disertasi Universitas Muhammadiyah Malang.2016;1-159.

27. Conil JM, Georges B, Ravat F, Ruiz S, Seguin T, Metsu D, et al. Ceftazidime dosage recommendations in burn patients: From a population pharmacokinetic approach to clinical practice via monte carlo simulations. Clinical Therapeutics. 2013;35(10):1603-12.

28. Coetzee E, Rode H, Kahn D. Pseudomonas aeruginosa burn wound infection in a dedicated paediatric burns unit. South African Journal of Surgery. 2013;51(2):50-3.

29. Putra ON, Saputro ID, Nurrahman ND, Herawati ED, Dewi LK. Effects of empirical antibiotic administration on the level of c-reactive protein and inflammatory markers in severe burn patients. Annals of Burns and Fire Disasters. 2020;33(1):20-6.

30. Putra ON, Saputro ID, Hidayatullah AYN. A retrospective surveillance of the prophylactic antibiotics for debridement 
surgery in burn patients. International Journal of Burns and Trauma. 2021;11(2):96-104.

31. Wirda A, Wiraningtias NB, Inayatilah FR, Indrawijaya YYA. Evaluation of Antibiotics Use in Post-Surgical Acute Appendicitis Patients at ThePasuruan Regency General Hospital in 2018 (The Study Was Conducted atInpatient Installation of Pasuruan Regency General Hospital). Pharmaceutical Journal of Indonesia. 2020;6(1):15-20. 